\title{
EFFICIENCY OF THE PRINCIPLE OF SUSTAINABLE DEVELOPMENT IN THE EUROPEAN UNION LAW
}

doi: 10.2478/cqpi-2019-0028

Date of submission of the article to the Editor: 28/04/2019

Date of acceptance of the article by the Editor: 01/06/2019

\author{
Ewa Kozień ${ }^{1}$ - orcid id: 0000-0002-5876-2804 \\ Adam Kozień ${ }^{2}$ - orcid id: 0000-0002-9301-9645 \\ ${ }^{1}$ Cracow University of Economics, Faculty of Economics and International Relations, \\ Department of Management Strategy and Organization, ul. Rakowicka 27, 31-510 Cracow, \\ Poland \\ 2Jagiellonian University in Cracow, Faculty Law and Administration, ul. Gołębia 24, 31-007 \\ Cracow, Poland
}

Abstract: The principle of sustainable development is one of the key principle of the European Union law. The principle of sustainable development has its source in the idea of sustainable growth, which is interdisciplinary in the nature and is based on the three basic aspects: economical, social and ecological. The aim of the paper is to analyze the European Union law from the point of view of the sustainable development principle and evaluation of the effectiveness of the principle in the European Union law. Keywords: efficiency, European Union law, sustainable development

\section{INTRODUCTION}

The sustainable development principle was introduced for the purpose of protecting the environment, exploited and destroyed by extensive human activity (Kielin-Maziarz, 2013), however it originated in the 19th century at the beginning of the industrial era/revolution and was found in the papers of M. Sommerville (Kielin-Maziarz, 2013). The actual implementation of this concept was possible thanks to introducing legal instruments in the local, national and international law. The sustainable development principle, present in the international legislation, as well as in particular countries, became a legal rule or a norm, especially with respect to administrative law (SkrzydłoNiżnik and Dobosz, 2003; Kozień, 2017). This idea was introduced in primary and secondary legislation of the European Union, constituting a principle in the European Union law.

It has an interdisciplinary character synthetically presented by D. Pearce and R.K. Turner in the statement that the sustainable development depends on maximizing net benefits of the economic growth with simultaneous protection and renewability of usability and quality of natural resources in the long run. The economic development leads not only to increase of income per capita but also to improvement of social wellbeing. Furthermore, it must include indispensable structural changes in the economy 
and the society (Pearce and Turner, 1990). The concept of sustainable development consists of three basic aspects: economic, social and environmental (Adamczyk and Nitkiewicz, 2007). It has to be emphasized that the idea of sustainable development differs from the perspective of scientific development and practical applications. Differences in viewpoints are particularly noticeable in economic and social aspects (Baker, 2003; Boyle and Freestone, 2012; Cordonier Segger and Khalfan, 2012; KielinMaziarz, 2013; Meadows et al., 1972; Ramlogan, 2011; Jacobs, 1991). The concept of sustainable development is not consistent, thus difficult to implement into the European Union law, which has to be coherent (Kozień and Kozień, 2018). The evaluation of the effectiveness of sustainable development in the EU law has to be conducted not only with respect to the primary and secondary legislation but also in the context of its effective legal.

The aim of the paper is to analyze the European Union law from the point of view of the sustainable development principle and evaluation of the effectiveness of the principle in the European Union law.

\section{THE MEANING OF EFFECTIVENESS}

The idea of effectiveness is not unequivocal. In praxeological doctrine it is equivalent to the notion of efficiency in universal terms. However, it has to be emphasized that the word efficiency is semantically broader than effectiveness as it may refer to general evaluation of activities including efficiency (defined as action that leads to achieving the aim), advantage (magnitude expressed in value units) and economics (expressed as the ratio of useful outcome to the costs of action). The literature defines effectiveness as the ability of organization to achieve aims (Pszczołowski, 1978). It has to be emphasized that the effectiveness is related to praxeological efficiency.

T. Pszczołowski, who represents praxeological school, suggested some interpretations of effectiveness in the context of organization and related it to:

- action - effective action leads to positive results,

- evaluation of the "outcome to aim" relation (Pszczołowski, 1978).

On the other hand, P. Ducker indicated complementary characters of effectiveness and efficiency and further defined efficiency as "doing the right things" and effectiveness as "doing things properly" (Drucker, 1995). This indication is the quality of management and both evaluations focus on the outcome.

M. Holstein-Beck presented extended interpretation of effectiveness which distinguishes six categories of this notion (Holstein-Beck, 1987):

1. efficiency (by T. Kotarbiński),

2. performance (by H. Emerson),

3. competence (by M. Weber),

4. functionality (by R. Beckhard),

5. communication (by Lawless),

6. morality (by K. Obuchowski and B.K. Saanlan).

The problem of effectiveness of law and its application is discussed in legal doctrine. It has to be stated that the European Union law applies the effectiveness principle (effet utile) which is treated as a self-contained rule or as resulting from the principle specified in article 4 paragraph 3 of the European Union Treaty (Barcz et al., 2015). The effectiveness principle depends on the necessity to achieve the aim in the right way and is related to the principle of loyal cooperation (Barcz et al., 2015). The effectiveness principle is especially important in the EU Court of Justice jurisdiction. S. Biernat notices 
that reference in jurisdiction to the effectiveness of the Community law is an interpretation principle, which instructs the Court of Justice to create legal norms such that they would enable achieving aims indicated by the law (Barcz et al., 2015).

\section{THE EFFECTIVENESS OF SUSTAINABLE DEVELOPMENT PRINCIPLE IN THE EUROPEAN UNION LAW}

The sustainable development principle may be noticed already in the Single European Act from 1986 (Single European Act), however in its literal meaning this concept appeared in Treaty of Maastricht in 1992 (Treaty on European Union). Further, sustainable development was included in the principles of Treaty of Amsterdam of 1997 (Treaty of Amsterdam).

The Treaty on European Union (TEU) refers to sustainable development in the Preamble, which according to the doctrine is treated as a system founding rule of the European Union. Nevertheless, it has to be stated that Preambles should be used for interpretation of law rather than word for word application of the contents (using normative text). Therefore, if only the Preamble is taken into consideration the sustainable development principle should not be treated as a system founding rule (Kozień and Kozień, 2018). Further, this concept was indicated in article 3 paragraph 3 subparagraph 1 and article 3 paragraph 5 of the Treaty on European Union among the aims of EU. The Union legislator states in article 3 paragraph 5 of the Treaty on European Union that: „The Union shall establish an internal market. It shall work for the sustainable development of Europe based on balanced economic growth and price stability, a highly competitive social market economy, aiming at full employment and social progress, and a high level of protection and improvement of the quality of the environment. It shall promote scientific and technological advance" (Treaty on European Union). According to this law the employer in the EU refers to social, economic and environmental aspects of the sustainable development, thus the analysis of article 3 of TEU indicates that the sustainable development principle is the aim of the EU within economic, environmental and even social aspects presenting functionally article 3 of TEU. The elements of sustainable development principle can also be found in article 21 paragraph 2 letter $d$ and $f$ of TEU, which regulates the aims of specifying and pursuing Union's policies and activities as well as ensuring high degree of cooperation in all fields of international relations.

In the context of sustainable development principle the Treaty on the Functioning of the European Union contains article 5 which constitutes the principle of subsidiarity, important for environmental protection. Also article 11 of the TFEU contains the principle of integration and sustainable development but refers strictly to the environmental aspect of the sustainable development: „Environmental protection requirements must be integrated into the definition and implementation of the Union's policies and activities, in particular with a view to promoting sustainable development" (Treaty on the Functioning of the European Union). The issue of environmental protection appears in the title XX of the TFEU called 'Environment' and according to the article 191 paragraph 3 of the TFEU, formation of the Union's environmental policy should be based on sustainable development. The discussed Treaty contains article 309 of the TFEU in principio, in which the EU employer focuses on economic aspect of the concept and principle of sustainable development by appealing to sustainable and stable development of internal market thus, sensu largo, it can refer to the principle of 
sustainable development (when taking into account the article 3 of the TEU). This concept also appears in Declaration on Article 126 of the Treaty on the Functioning of the European Union paragraph 5, which mentions balanced economic growth (a concept derived from sustainable development but of narrower meaning). The analysis of the discussed paragraph 5 of the Declaration apparently indicates extensive influence of balanced economic growth on the economic and financial policy of the European Union but it is a Declaration to article 126 of the TFEU, which is concerned with budget deficit.

The concept of sustainable development can be also found in the secondary legislation of the EU in the following acts: Regulation of the European Parliament and Council (EU) number 305/2011 from 9th March 2011 establishing consistent conditions for the turnover of building materials and repealing the Council directive 89/106/EEC, European Parliament and Council Directive 2012/27/EU from 25th October 2012 on energy efficiency, changes of directives 2009/125/EC and 2010/30/EU and repealing directives 2004/8/EC and 2006/32/EC, European Parliament and Council Directive 2009/147/EC from 30th November 2009 concerning the protection of wildfowl, European Parliament and Council Directive 2014/52/EU from 16th April 2014 changing the directive 2011/92/EU regarding the evaluation of impact of certain public undertakings and private projects on the environment, European Parliament and Council Directive 2003/4/EC from 28 January 2003 regarding the access of public opinion to the information about the environment and concerning repealing the directive 90/313/EEC. Moreover, environmental programs and strategies are implemented in the European Union on the basis of the sustainable development principle, for instance, Strategy „Europe 2020”.

\section{CONCLUSIONS}

In conclusion, it has to be stated that the sustainable development principle was not holistically implemented into the legal system of the European Union, though it is treated as a system founding rule of the EU. Furthermore, the emphasis should be put on the fact that this concept is internally inconsistent, which may be an obstacle to its implementation into the EU law (which cannot be internally inconsistent). It is worth mentioning that sustainable development principle was not included in the system of EU values (article 2 TEU) but among the aims of the EU, which is appropriate when considering the inconsistent nature of this principle (Kozień and Kozień, 2018). Furthermore, sustainable development principle in the Union's primary and secondary legislation refers only to the environmental aspect of this principle.

The evaluation of effectiveness of sustainable development principle can be conducted only with respect to the environmental aspect because as a rule, this principle was not implemented into EU law. Both primary and secondary legislation implement the concept of sustainable development in the environmental aspect. From the effectiveness perspective, there are numerous acts of the EU secondary legislation which are based on the concept of sustainable development existing in primary legislation. As a result, this principle can be implemented and have impact on the EU and member states. The effectiveness of applying the sustainable development principle may be negatively influenced by an inconsistent nature of this concept. Thus, one can ask a question, which viewpoint should be considered valid by the EU employer. For this reason, it is necessary to introduce more details into this principle in the European Union secondary legislation. 
In summary, the concept of sustainable development is not consistent thus, undermines the effectiveness of sustainable development principle in the EU legal system. This principle lacks effectiveness in the EU legal system with respect to economic and social aspects. It can be positively evaluated only in terms of environmental aspect. To put it in other words, the sustainable development principle should not be considered as a system founding rule of EU because it derives from the concept of sustainable development which is not internally consistent.

The presented view of the sustainable development should be of interest for technology researcher, because their investigations, obtained results and derived new technologies are tools to make basis for this development. In fact, materials science is the rich source to achieve new technological possibilities through the modification of a material structure (Lipinski, 2015; Szczotok et al., 2018), its surface layer (Radek et al., 2014) or special coating deposition (Skoneczny and Bara, 2007; Bara et al., 2016; Radek et al., 2018) or creation of sintered components (Dudek and Kolan, 2010). Similarly, phytochemistry investigations (Skrzypczak-Pietraszek et al., 2018b) and biotechnological researches (Skrzypczak-Pietraszek et al., 2018b) are the second source of sustainable technologies.

\section{REFERENCES}

Adamczyk, J., Nitkiewicz, T., 2007. Programming of Sustainable Development of Enterprises (in Polish), PWE, Warszawa.

Baker, S., 2003. The European Union: Integration, Competition, Growth-And Sustainability [in:] Lafferty, W.M., Meadowcroft, J., Implementing Sustainable Development: Strategies and Initiatives in High Consumption Societes, Oxford Scholarship Online, Oxford.

Bara, M., Kmita, T., Korzekwa, J., 2016. Microstructure and properties of composite coatings obtained on aluminium alloys. Arch. Metall. Mater., 61, 1107-1112. DOI: 10.1515/amm-2016-0238

Barcz J., Górka M., Wyrozumska A., 2015. Institutions and European Union Law (in Polish), Wolters Kluwer, Warszawa.

Boyle, A., Freestone, D., 2012. International Law and Sustainable Development: Past Achievements and Future Challenges, Oxford Scholarship Online, Oxford.

Consolidated versions of the Treaty on European Union and the Treaty on the Functioning of the European Union, Official Journal of the European Union, C 202 of 7.6.2016, (Treaty of Lisbon).

Cordonier-Segger, M.C., Khalfan, A., 2012. Sustainable Development Law: Principles, Practices, and Prospects, Oxford Scholarship Online, Oxford.

Drucker P., 2006. Management in Turbulent Times, Harper Business.

Dudek, A., Kolan, C., 2010. Assessments of Shrinkage Degree in Bioceramic Sinters $H A+Z r O(2)$. Solid State Phenomena, 165, 25-30. DOI: 10.4028/www.scientific.net/SSP.165.25

Holstein-Beck M., 1987. Notes about Labour (in Polish), Wydawnictwo Książka i Wiedza, Warszawa.

Jacobs,M., 1991. The Green Economy, Sustainable Development and the Politics of the Future, London.

Kielin-Maziarz, J., 2013. Concept of Sustainable Development in European Union Law (in Polish), Wydawnictwo KUL, Lublin. 
Kozień A., 2017. Administrative law conditions of economical concept of sustainable development (in Polish), [in:] Kruk E., Lubeńczuk G., Drab T., Development trends in administrative law (in Polish), Wydawnictwo UMCS, Lublin, 147-162.

Kozień E., Kozień A., 2018. The sustainability development concept under the regulations in force of the Treaty on European Union and the Treaty on the Functioning of the European Union - legal and economical view, $35^{\text {th }}$ Int. Scientific Conf. Economic and Social Development Lisbon, Varazdin, 402-412.

Lipinski, T., 2015. Double modification of AlSigMg alloy with boron, titanium and strontium. Arch. Metall. Mater., 60, 2415-2419. DOI: 10.1515/amm-2015-0394

Meadows, D.H., Meadows, D.L., Randers, J., 1972. The Limits to Growth, New York.

Pearce, D., Turner, R.K., 1990. Economics of Natural Resources and Environment, Aldershot/Brookfield, New York.

Pszczołowski T., 1978. Small encyclopedia of praxeology and theory of organization (in Polish), Zakład Narodowy im. Ossolińskich, Wrocław-Gdańsk.

Radek, N., Pietraszek, J., Antoszewski, B., 2014. The Average Friction Coefficient of Laser Textured Surfaces of Silicon Carbide Identified by RSM Methodology. Adv. Mat. Res.-Switz., 874, 29-34. DOI: 10.4028/www.scientific.net/AMR.874.29

Radek, N., Szczotok, A., Gadek-Moszczak, A., Dwornicka, R., Broncek, J., Pietraszek, J., 2018. The impact of laser processing parameters on the properties of electrospark deposited coatings. Arch. Metall. Mater., 63, 809-816. DOI: 10.24425/122407

Ramlogan, R., 2011. Sustainable Development: Towards Judicial Interpretation, Boston Martinus Nijhoff Publishers, Leiden.

Single European Act, Official Journal of the European Union, No L 169/1 of 29.6.87.

Skoneczny, W., Bara, M., 2007. Aluminium oxide composite layers obtained by the electrochemical method in the presence of graphite. Materials Science-Poland, 25, 1053-1062.

Skrzydło-Niżnik, I., Dobosz, P., 2003. Concept of sustainable development in system of law and doctrine of administrative law (in Polish), [in:] Individual in Democratic State of Law (in Polish), Wyższa Szkoła Administracji, Bielsko-Biała, 614-628.

Skrzypczak-Pietraszek E., Piska, K., Pietraszek, J., 2018a. Enhanced production of the pharmaceutically important polyphenolic compounds in Vitex agnus castus L. shoot cultures by precursor feeding strategy. Enginnering in Life Sciences, 18, 287-297. DOI: $10.1002 /$ elsc.201800003

Skrzypczak-Pietraszek, E., Reiss, K., Zmudzki, P., Pietraszek, J., 2018b. Enhanced accumulation of harpagide and 8-O-acetyl-harpagide in Melittis melissophyllum L. agitated shoot cultures analyzed by UPLC-MS/MS. PLoS ONE 2018, 13, art. e0202556. DOI: 10.1371/journal.pone.020255610.1371/journal.pone.0202556

Szczotok, A., Radek, N., Dwornicka, R., 2018. Effect of the induction hardening on microstructures of the selected steels. METAL 2018: 27 ${ }^{\text {th }}$ Int. Conf. Metallurgy and Materials. Ostrava, Tanger, 1264-1269.

Treaty of Amsterdam amending the Treaty on European Union, the Treaties establishing the European Communities and certain related acts - Final Act, Official Journal of the European Union, C 340 of 10.11.1997.

Treaty on European Union, Official Journal of the European Union, No C 191/1 of 29.7.92, (Treaty of Maastricht). 